\title{
Prevalence of use of alcohol, tobacco, cocaine and other illicit drugs among drivers truck in the West Center region of Brazil
}

\author{
Prevalência do uso de álcool, tabaco, cocaína e outras drogas ilícitas entre motoristas de caminhão \\ da região Centro-Oeste do Brasil \\ Prevalencia del consumo de alcohol, tabaco, cocaína y otras drogas ilícitas entre los camioneros de \\ la región del Medio Oeste de Brasil
}

Received: 06/26/2021 | Reviewed: 07/06/2021 | Accept: 07/11/2021 | Published: 07/22/2021

Carla Danielle Dias Costa

ORCID: https://orcid.org/0000-0002-0107-9932

Universidade Federal de Goiás, Brazil

E-mail: carladaniellebm@gmail.com

Diogo Sousa Rodrigues

ORCID: https://orcid.org/0000-0001-9579-4541

Universidade Federal de Goiás, Brazil

E-mail: diogosrodrigues11@gmail.com

Flávia Neri Meira

ORCID: https://orcid.org/0000-0002-5417-4132

Secretaria de Estado da Saúde do Distrito Federal, Brazil

E-mail: neri.meira@gmail.com

Sérgio Henrique Nascente Costa

ORCID: https://orcid.org/0000-0002-4225-6368

Universidade Federal de Goiás, Brazil

E-mail: sergionascente@yahoo.com.br

Vania Rodriguez

ORCID: https://orcid.org/0000-0002-9842-0489

Pontifícia Universidade Católica de Goiás, Brazil

E-mail:vaniaro2009@gmail.com

Alessandro de Carvalho Cruz

ORCID: https://orcid.org/0000-0002-8878-1678 Universidade Federal de Goiás, Brazil

E-mail: alesscruz@yahoo.com.br

Jerônimo Raimundo de Oliveira Neto

ORCID: https://orcid.org/0000-0002-0261-4554

Universidade Federal de Goiás, Brazil

E-mail: jeronimoneto8@gmail.com

Luiz Carlos da Cunha

ORCID: https://orcid.org/0000-0002-1525-8528 Universidade Federal de Goiás, Brazil

E-mail: lucacunha@gmail.com

Keila Correia de Alcantara

ORCID: https://orcid.org/0000-0002-4477-2833

Universidade Federal de Goiás, Brazil

E-mail: keilalcantara7@gmail.com

\begin{abstract}
The aim of this study was to estimate the prevalence of use of licit and illicit drugs and verify the behavioral profile among truck drivers. A total of 697 truck drivers were interviewed at a gas station on BR-153, between from February 2014 to February 2015. The questionnaire ASSIST was applied to screening the use of alcoholic beverages, tobacco and illicit drugs. Sociodemographic information and professional were also collected. Urine samples were screened for licit and illicit drugs. All of truckers were male, median age of 42 years, most of them married and low scholarity. $47 \%$ related moderate or high consumption of alcohol and tobacco and need a brief intervention. $21 \%$ use of cocaine, cannabinoids, amphetamine, hypnotics/sedatives, opioids, inhalants and need specialist treatment. From the 697 participants, $94 \%$ provided urine samples. $10,5 \%$ were positive for drugs. 5,2\% were positive for cocaine, $2,6 \%$ for cannabinoids, $2,0 \%$ for amphetamine, $0,4 \%$ for benzodiazepines, $0,3 \%$ positive for methamphetamines and $1,4 \%$ for combined use of two drugs. Young and single truckers use tobacco, cannabis and amphetamines and need to receive brief intervention for these drugs. Truck drivers in the northern region of low education, require specialized treatment for tobacco. Truck drivers make high use of tobacco, alcohol, cocaine and other ilicit drugs. Measures are needed to
\end{abstract}


improve quality of life to the drivers, as well as to prevent and treat individuals who use licit and illicit drugs in order to reduce engagement with traffic accidents.

Keywords: Immunoassay; Psychoactive substance; ASSIST; Urine.

\begin{abstract}
Resumo
O objetivo deste estudo foi estimar a prevalência do uso de drogas lícitas e ilícitas e verificar o perfil comportamental de caminhoneiros. Foram entrevistados 697 motoristas de caminhões em um posto de gasolina da BR-153, de fevereiro de 2014 a fevereiro de 2015. O questionário ASSIST foi aplicado para rastreamento do uso de bebidas alcoólicas, tabaco e drogas ilícitas. Informações sociodemográficas e profissionais também foram coletadas. Amostras de urina foram testadas para drogas lícitas e ilícitas. Todos os caminhoneiros eram do sexo masculino, idade mediana de 42 anos, a maioria casados e com baixa escolaridade. $47 \%$ relataram consumo moderado ou alto de álcool e tabaco e precisariam de uma intervenção breve. $21 \%$ consumiam cocaína, canabinoides, anfetaminas, hipnóticos/sedativos, opioides, inalantes e necessitam de tratamento especializado. Dos 697 participantes, 94\% forneceram amostras de urina. $10,5 \%$ foram positivos para drogas. 5,2\% foram positivos para cocaína, 2,6\% para canabinoides, 2,0\% para anfetaminas, $0,4 \%$ para benzodiazepínicos, $0,3 \%$ para metanfetaminas e 1,4\% para uso combinado de duas drogas. Caminhoneiros jovens e solteiros usavam tabaco, maconha e anfetaminas e precisavam receber intervenção breve para essas drogas. Aos caminhoneiros da região Norte, com baixa escolaridade, o tratamento especializado para o tabagismo era necessário. Os caminhoneiros fazem alto uso de tabaco, álcool, cocaína e outras drogas ilícitas. São necessárias medidas para melhorar a qualidade de vida dos motoristas, bem como prevenir e tratar os usuários de drogas lícitas e ilícitas, a fim de reduzir o envolvimento em acidentes de trânsito.
\end{abstract}

Palavras-chave: Imunoensaio; Substâncias psicoativas; ASSIST; Urina.

\title{
Resumen
}

Se estimó la prevalencia del uso de drogas lícitas e ilícitas y verificar el perfil de comportamiento de los camioneros. Se entrevistó a 697 camioneros en una gasolinera de la BR-153, de febrero 2014 a febrero 2015. Se aplicó el cuestionario ASSIST para rastrear el consumo de bebidas alcohólicas, tabaco y drogas ilícitas. También se recogió información sociodemográfica y profesional. Se analizaron muestras de orina para detectar drogas lícitas e ilícitas. Los conductores de camiones eran hombres, con una edad media de 42 años, la mayoría de los cuales estaban casados y tenían un nivel educativo bajo. El $47 \%$ informó un consumo moderado o alto de alcohol y tabaco y necesitaría una breve intervención y $21 \%$ consumía cocaína, cannabinoides, anfetaminas, hipnóticos/sedantes, opioides, inhalantes y necesitan tratamiento especializado. De los 697 participantes, el 94\% proporcionó muestras de orina. El 10,5\% fueron positivos a fármacos; $5,2 \%$ fueron positivos para cocaína, 2,6\% para cannabinoides, 2,0\% para anfetaminas, $0,4 \%$ para benzodiazepinas, $0,3 \%$ para metanfetaminas y 1,4\% para el uso combinado de drogas. Los conductores de camiones jóvenes y solteros consumían tabaco, marihuana y anfetaminas y necesitaban recibir una breve intervención. Para los camioneros de la región Norte, con bajo nivel educativo, era necesario un tratamiento especializado para el tabaquismo. Los camioneros consumen mucho tabaco, alcohol, cocaína y otras drogas. Se necesitan medidas para mejorar la calidad de vida de los conductores, así como para prevenir y tratar a los usuarios de drogas, con el fin de reducir la participación en accidentes de tráfico.

Palabras clave: Inmunoensayo; Sustancias psicoactivas; ASSIST; Orina.

\section{Introduction}

The cargoes transportation in Brazil has a great importance to the Brazilian economy, represented by a fleet of approximately 2.8 million trucks, which travels by the highways. This high quantity of vehicles is because land transport system loads is the primary means of economic development and the country demands for supplies (CNT, 2021).

The population of professional drivers in Brazil is made up of about 1,013,089 truckers (Brasil, 2021). Brazilian law no. 13103 from March of 2015 regulates the exercise of truck drivers, but it is not properly enforced. Some participants do not perform adequate rest breaks or meals, they exceed the working-hours per day because of the goals to be achieved, increasing the risk of involvement in traffic accidents. Due to several factors they present problems related to health and lifestyle (Alessi and Alves, 2015), and high vulnerability to risk practices, such as smoking, high consumption of alcohol and illicit substances such as amphetamines, marijuana and cocaine (Knauth et al., 2012).

Many articles have been published about the use and abuse of drugs by truck drivers in Brazil (Silva et al., 2003; Leyton et al., 2011; Oliveira et al., 2013; Yonamine et al., 2013, Pereira et al., 2021). They showed that driving under the influence of alcohol or drugs, high speed and young age, are major risk factors related to the number of traffic accidents on the roads. 
The west-center region of Brazil is the principal axis of flow between the northern/northeast and south/southeast regions of the country and few or none study specifically in this region with this kind of population is actually available. Thus, this study aimed to estimate the prevalence of illicit drug use by truck drivers passing through the middle-west region from Brazil.

\section{Methodology}

\subsection{Study Settings}

This is a cross-sectional, quantitative, descriptive study and was conducted at a gas station on BR-153, in Goiânia city, west center region of Brazil between February 2014 and February 2015.

\subsubsection{Study design and population}

In this cross-sectional descriptive study, 697 truck drivers were interviewed about the use of alcohol, tobacco, cocaine and others illicit drugs and urine samples of the ones who accepted donate were collected.

\subsection{Ethical Considerations}

The research and ethics committee of the Universidade Federal de Goiás approved the study. All participants recruited provided written informed consent.

\subsection{Volunteers and Procedures}

Specific days of the week and weekend were selected to collect urine samples and interview truck drivers from February of 2014 to February of 2015. Truck drivers who parked at the chosen gas station to refuel, reload, eat and/or rest were approached randomly by researchers. They were informed of the goals of the study and signed a consent form. They answered the questionnaire and provided urine samples. It was clarified that the participant may only fill the questionnaire without collect urine samples, if he preferred.

The questionnaire used is called Alcohol, Smoking and Substance Involvement Screening Test (ASSIST). It has a goal to investigate the frequency of consumption in the last three months of licit drugs as alcoholic beverages, tobacco and illicit drugs such as cannabinoids, cocaine, amphetamine or ecstasy, inhalants, hypnotics/sedatives, hallucinogens, and opioids. Sociodemographic information (age, sexual orientation, marital status, education, region of residence), professional characteristics (origin and truck cargoes destination, time away from home) were also searched. Additionally, they answered about health problems as previous sexual transmitted infections (STIs).

The ASSIST questionnaire was developed and validated by the World Health Organization (WHO). It contains eight questions and it was designed to be administered by a health worker to any participant and it takes about 5-10 minutes to apply (Humeniuk et al., 2010).

\subsection{Sample Collection and Analyses}

Study participants (697) were selected by convenience sampling. Of those, 656 agreed to provide urine samples. To ensure the confidentiality of the volunteers, questionnaires and urine collection tubes were only identified with a code number. Urine samples were collected using plastic (polypropylene) collection tubes, and the samples were stored in a freezer $-20^{\circ} \mathrm{C}$ until they were analysed a few days later. For drug screening, Instant View ${ }^{\circledR}$ kit (Bioeasy) for ten drugs was used. The monitored drugs by this kit were morphine (MOR), amphetamine (AMP),methamphetamine (MET), tricyclic antidepressants (TCA), MDMA or Ecstasy (XTC), benzodiazepines (BZD), cocaine (COC), methadone (MTD), barbiturates (BAR), cannabinoids/ cannabis (THC) metabolites. The following cut-off values were used in the screening test: morphine (MOR) - 2,000 ng/mL; 
Amphetamine (AMP), methamphetamine (MET), tricyclic antidepressants (TCA) - $1000 \mathrm{ng} / \mathrm{ml}$; Ecstasy or MDMA (XTC) - 500 $\mathrm{ng} / \mathrm{ml}$; Cocaine (COC), Benzodiazepines (BZD), Methadone (MTD) - $300 \mathrm{ng} / \mathrm{mL}$; Barbiturates (BAR) - $200 \mathrm{ng} / \mathrm{ml}$ and cannabinoids/cannabis (THC) - $50 \mathrm{ng} / \mathrm{ml}$. The toxicological analysis of biological material was carried out in Núcleo de Estudos e Pesquisas Tóxico-Farmacológicas from the Universidade Federal de Goiás (NEPET/UFG).

\subsection{Data analysis}

Sociodemographic data, professional characteristics and health problems were processed and analyzed using the software Epi Info Version 7.1.0.6 for Windows. Basics descriptive statistics were performed, including percentage frequency, median and means. The analysis of the ASSIST answers was done by adding scores of questions 2 to 7 . The truckers who have score 10 for alcohol or even 3 for other drugs, are considered as occasional users with low risk. When the score is between 11 and 26 for alcohol and between 4 and 26 for other drugs is interpreted as the use of harmful risk. Scores above 26 for any drug are considered high risk for dependence. The score for each substance which was used by the participant determines the most appropriate intervention for that level of use ('no treatment', 'brief intervention' or 'referral to specialist assessment and treatment respectively) (Humeniuk et al., 2010).

To analyse the association between the variables was used multiple correspondence analysis (MCA) and hierarchical cluster analysis (HCA). The variables analyzed were sociodemographic data (age, sexual orientation, level of education, marital status - for married individuals or stable, relationship - time, number of fixed and/or casual partners, fixed region of residence); occupational information (destination region and origin of the cargoes, time away from home), previous exposure to STIs, the answers to the questionnaire ASSIST and the results of toxicological analysis. The statistical program used was the Système d`Analyse Portable Package - SPAD, Version 7.4 (Lebart; Morineau; Lambert, 1994). The $p$ values less than 0.05 were considered significant (Greenacre, 2007).

\section{Results}

\subsection{Sociodemographic, professional characteristics and health problems}

A total of 697 truck drivers were interviewed. All of them were male, heterosexual. The median age was 42 years (range of age between $20-72$ years). More than 70\% $(n=518)$ were married or were in a stable relationship and 65\% ( $n=451)$ of them had over 5 years of relationship. Approximately 38\% $(n=261)$ and 29\% (202) of truck drivers lived in the Southeast and South of Brazil, respectively. 60\% $(\mathrm{n}=419)$ of participants had less than eight years of scholarity. In relation to occupational information 37\% ( $n=260)$ truckers acquired their loads in the Southeast and South and 52\% $(n=362)$ of cargoes were destined for the Midwest region of the country. 38\% ( $n=265)$ of participant was between 15 and 30 days away from home. About the health information, 23\% ( $\mathrm{n}=159)$ of truck drivers reported having had sexual transmitted infection (STI) at least once in life. Table 1 , shows in detail the obtained results of the socio-demographic profile, occupational and health problems of the participants. 
Table 1. Socio-demographic profile, occupation information and health problems of the volunteer truck drivers male approached the Gas Station located at BR153 in the period February 2014 to February 2015 ( $\mathrm{n}=697)$.

\begin{tabular}{|c|c|c|c|}
\hline Variables & & $\mathbf{n}$ & $\%$ \\
\hline & Heterosexual & 694 & 99,6 \\
\hline \multirow[t]{3}{*}{ Sexual Orientation } & Homosexual & 2 & 0,3 \\
\hline & Bisexual & 1 & 0,1 \\
\hline & $18-29$ years & 78 & 11,2 \\
\hline \multirow[t]{3}{*}{ Age Group } & $30-59$ years & 579 & 83 \\
\hline & $>60$ years & 40 & 5,8 \\
\hline & Married & 405 & 58,1 \\
\hline \multirow[t]{4}{*}{ Marital Status } & Stable union & 113 & 16,2 \\
\hline & Single & 109 & 15,6 \\
\hline & More 5 years & 451 & 65 \\
\hline & 1 to 5 years & 59 & 8,5 \\
\hline & Less than 1 year & 7 & 1 \\
\hline & Elementary School & 419 & 60 \\
\hline \multirow{3}{*}{ Scholarity level } & High school & 246 & 35 \\
\hline & Graduated & 22 & 3 \\
\hline & Southeast Region & 261 & 37,5 \\
\hline \multirow[t]{3}{*}{ Region of residence } & South Region & 202 & 29 \\
\hline & West Center Region & 92 & 13 \\
\hline & Southeast Region & 260 & 37 \\
\hline \multirow[t]{3}{*}{ Region of origin of cargoes } & South Region & 155 & 22 \\
\hline & West Center Region & 142 & 20 \\
\hline & West Center Region & 362 & 52 \\
\hline \multirow[t]{3}{*}{ Region of destiny of cargoes } & Southeast Region & 133 & 19 \\
\hline & North Region & 83 & 12 \\
\hline & Between 15 and 30 days & 265 & 38 \\
\hline \multirow[t]{3}{*}{ Time away from home } & Between 7 and 15 days & 227 & 32,5 \\
\hline & Between 3 and 7 days & 97 & 14 \\
\hline & Had previous STIs & 159 & 23 \\
\hline \multicolumn{4}{|l|}{ Health problems } \\
\hline & Not had previous STIs & 526 & 75,5 \\
\hline
\end{tabular}




\subsection{Alcohol, Smoking and Substance Involvement Screening Test - ASSIST results}

From 691 truck drivers who answered the questions, 47\% $(n=332)$ related indiscriminate consumption of alcoholic drinks and tobacco as licit drugs. From these $47 \%, 31 \%$ and $16 \%$ consume tobacco and alcohol, respectively, and need to go through a brief intervention (BI) or are advised to seek specialist treatment (ST) for these drugs. $21 \%(\mathrm{n}=151)$ declared have used illicit drugs, such as cocaine/crack, cannabinoids, amphetamine, hypnotics/sedatives, opioids, inhalants in the last three months and need also to go to intervention or specialist treatment for the same. This results are presented in Table 2 .

Table 2. Self reporting on the ASSIST questionnaire about the abuse of licit and illicit drugs in the last three months of Brazilian professional drivers who had traveled on the BR 153 in 2014 to 2015 period $(n=691)$.

\begin{tabular}{|c|c|c|c|c|}
\hline & & & $\begin{array}{c}\text { Brief } \\
\text { intervention }\end{array}$ & $\begin{array}{c}\text { Specialist } \\
\text { Treatment }\end{array}$ \\
\hline & $\mathbf{n}$ & $\%$ & $\mathbf{n}$ & $\mathbf{n}$ \\
\hline \multicolumn{5}{|c|}{ LICIT } \\
\hline Tobacco & 218 & 31 & 200 & 18 \\
\hline \multirow[t]{2}{*}{ Alcohol } & 114 & 16 & 112 & 2 \\
\hline & TOTAL & 47 & & \\
\hline \multicolumn{5}{|c|}{ ILLICIT } \\
\hline Amphetamine / ecstasy & 88 & 12 & 86 & 2 \\
\hline Cocaine crack & 34 & 5 & 33 & 1 \\
\hline Cannabinoids & 19 & 2,7 & 19 & 0 \\
\hline Hypnotics / sedatives & 4 & 0,6 & 4 & 0 \\
\hline Opioids & 4 & 0,6 & 4 & 0 \\
\hline \multirow[t]{2}{*}{ Inhalants } & 2 & 0,3 & 2 & 0 \\
\hline & TOTAL & 21 & & \\
\hline
\end{tabular}

Source: Authors.

\subsection{Toxicological analysis}

A total of 697 long distance truck drivers from all regions of Brazil participated the study, from them 94\% $(\mathrm{n}=656)$ provided urine samples for being analyzed by immunoassay. 10,5\% $(n=69)$ of the samples were positive for one or more than one drug. From these positives samples, $5 \%$ were positive for cocaine, $2,4 \%$ for cannabinoids, $1,8 \%$ for amphetamine, $0,4 \%$ and $0,3 \%$ positive for benzodiazepines and methamphetamines, respectively and $1,3 \%(\mathrm{n}=9)$ for combined use of two drugs. $1,0 \%$ of these volunteers had positive results in the use associated of cocaine and cannabinoids and $0,3 \%$ used cocaine and substances with amphetamine compounds. All the results obtained by immunoassay are represented on Table 3. 
Table 3. Results of Immunoassay analysis (INSTANT VIEW ${ }^{\circledR}$ ) of drugs in urine samples truckers and distribution of positive cases according to drug group $(\mathrm{n}=656)$. COC $=$ Cocaine, MET=Methamphetamine, THC=Tetrahydrocannabinol, AMP= Amphetamine, BZD = Benzodiazepines.

\begin{tabular}{lll}
\hline DRUGS & $\mathrm{n}$ & $\%$ \\
\hline COC & 34 & 5,2 \\
THC & 17 & 2,6 \\
AMP & 13 & 2,0 \\
BZD & 3 & 0,4 \\
MET & 2 & 0,3 \\
More of one drug & 9 & 1,4 \\
\hline
\end{tabular}

Source: Authors.

\subsection{Multiple correspondence analysis (MCA) and Hierarchical Cluster Analysis (HCA)}

The multiple correspondence analysis generated $61 \%$ of the cumulative percentage of information and they are shown on the graph with two dimensions (Figure 1). There is the MCA chart in the first factorial axis (MC - 1) the separation of the younger truckers, 20-39 years old, single, separated and divorced, away from home more 30 days, with casual partners, cocaine users, who have or have had STIs, who should be submitted to brief intervention for amphetamines, cannabinoids and tobacco. In this group are also contemplated older truck drivers, 40 to 59 years, married, stable, steady partner, fixed housing, negative for drugs, which need not receive the intervention or treatment for any drug and degree education from 1st to 4th grade.

In the second factorial axis (MC - 2) there is the separation of single truck, separated, divorced, aged 20 to 29 years away from home more than 30 days of truck drivers aged over 30 years, cocaine users and tobacco and participants who has had STI at least once.

The Hierarchical Cluster Analysis grouped the truckers in five clusters preferably. In the first cluster $(n=41)$, were joined truckers who have fixed housing in the Midwest $(p=0.004)$, needed to be subjected to brief intervention for amphetamine $(p=0.021)$ and cannabinoids $(p=0.003)$ and not has STI $(\mathrm{p}=0.013)$. In the second cluster $(\mathrm{n}=45)$ there were separated truckers aged between 20 to 39 years ( $\mathrm{p}=0.007$ ), which were positive for cocaine use ( $<0.0001$ ), needed to receive brief intervention for amphetamine, cannabis and tobacco $(\mathrm{p}<0.0001)$. They also had occasional partners $(p=0.001)$ and they had STI $(\mathrm{p}=0.014)$. 


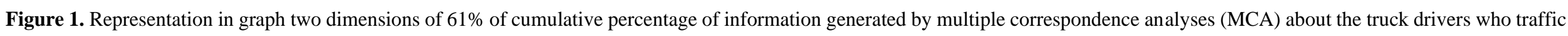
on the BR 153 in 2014 to 2015 period. STI = Sexual Transmission Infection.

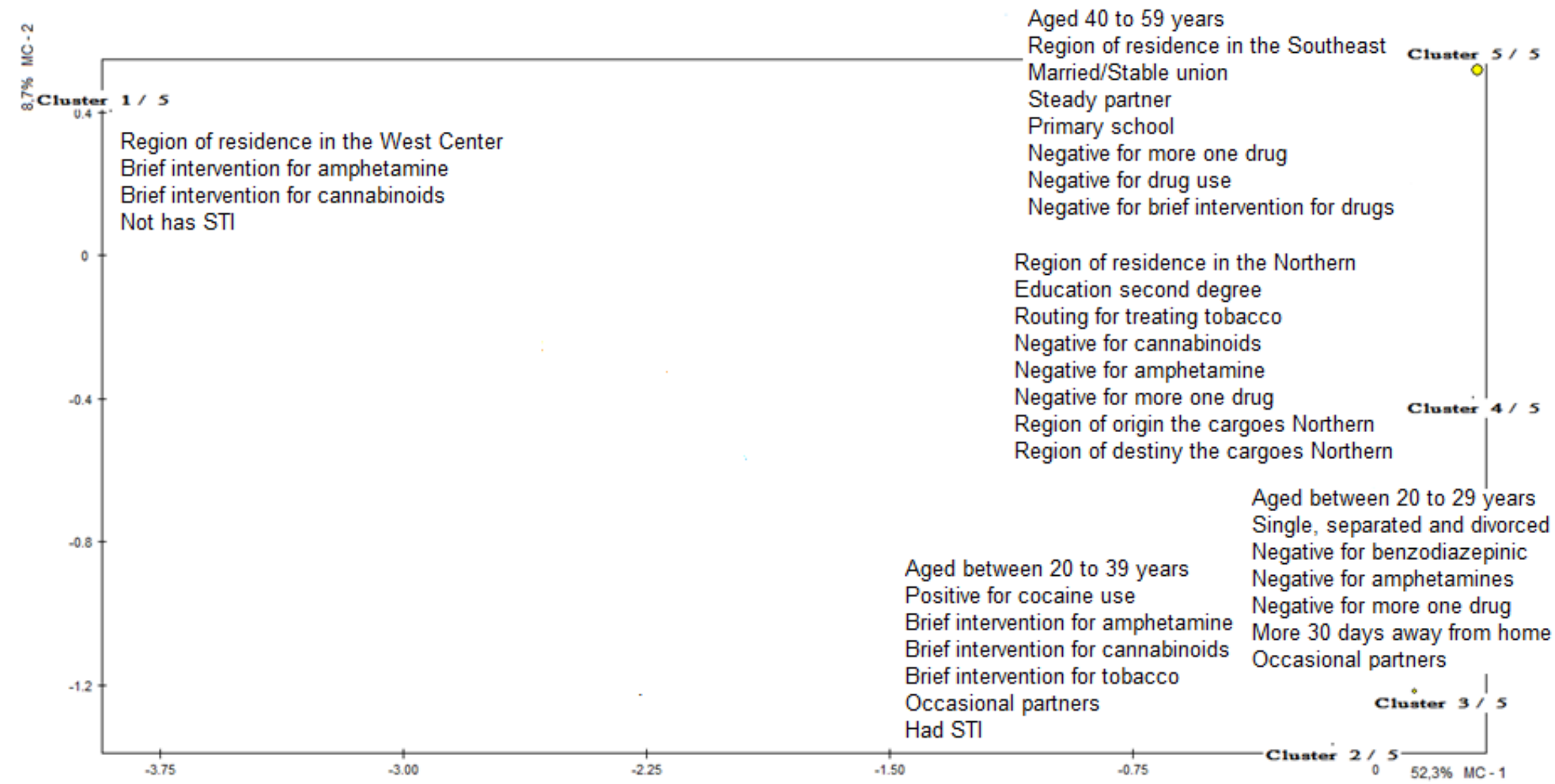

Source: Authors. 
In the third cluster $(n=129)$ were isolated truckers aged between 20 to 29 years $(p=0.003)$, single, separated and divorced $(\mathrm{p}<0.0001)$, with negative results for more than one drug $(p<0.0001)$, negative for benzodiazepines $(\mathrm{p}<0$, 0001), cocaine $(p<0.0001)$, THC $(p<0.0001)$ and amphetamines $(p=0.016)$. They staying away from home more than 30 days $(p=$ $0.001)$ and have occasional partners $(p<0.0001)$.

In the fourth cluster $(\mathrm{n}=52)$ there were joined truck drivers with fixed housing in the northern region of country ( $\mathrm{p}$ $<0.0001)$, education second degree $(\mathrm{p}=0.017)$, with routing for treating tobacco $(\mathrm{p}<0.0001)$ with negative results for THC $(\mathrm{p}=$ 0.009), amphetamines $(\mathrm{p}=0.012)$ and more than one drug $(\mathrm{p}=0.017)$ and the region of origin the cargoes was the northern region $(\mathrm{p}<0.0001)$ and destined for the northern region $(\mathrm{p}=0.014)$.

Finally, the fifth cluster $(n=430)$ were joined by truck drivers aged $40-59$ years $(p=0.004)$, with fixed housing in the southeast $(\mathrm{p}=0.010)$ and education between 1st to 4th grade $(\mathrm{p}=0.0018)$. Married truckers $(\mathrm{p}<0.0001)$, stable $(\mathrm{p}<0.0001)$, with a steady partner $(\mathrm{p}<0.0001)$, with more than 5 years together $(\mathrm{p}<0.0001)$, without casual partners $(\mathrm{p}<0.0001)$, with neg ative results for more than one drug ( $\mathrm{p}<0.0001)$, cocaine $(\mathrm{p}<0.0001)$, THC $(\mathrm{p}<0$, 0001), methamphetamine ( $\mathrm{p}<0.0001)$, amphetamine $(\mathrm{p}<0.0001)$ and benzodiazepines $(\mathrm{p}<0.0001)$ with no intervention to cocaine $(\mathrm{p}<0.0001)$, amphetamines $(\mathrm{p}$ $<0.0001)$, cannabinoids $(\mathrm{p}<0.0001)$, tobacco $(\mathrm{p}=0.001)$ and inhalants $(\mathrm{p}=0.006)$.

\section{Discussion}

There are a lot of articles about alcohol, tobacco and illicit drugs consumption in groups of truck drivers through questionnaires across the country (Oliveira et al., 2013; Berti et al., 2013; Takitane et al., 2013; Domingos et al., 2014, Oliveira et al., 2016, Pereira et al., 2021, Scherer et al., 2021). However, this one is the first study that estimated the prevalence of these drugs through a questionnaire validated by the World Health Organization (WHO), as well as the initiative to list the intervention procedures and/or treatment to be used in participants who do consume abuse of licit and illicit substances. The analysis of the responses to the questionnaire ASSIST identified that $31 \%$ of subjects reported indiscriminate use of tobacco and $16 \%$ of alcohol in the last three months. In the state of Minas Gerais, Nascimento et al. (2007) formulated and implemented a simple questionnaire and observed that $91 \%$ of truck drivers were using alcoholic beverages during working hours. High prevalence for this drug was also presented in other studies carried out by Knauth et al. (2012), Takitane et al. (2013), Peixe et al. (2014). In a study on the highways of São Paulo, Takitane et al. (2013) showed that the rate of $23 \%$ of truckers were smokers, showing the number of participants who make the daily consumption of tobacco. The II Data of National Alcohol and Drug Survey (II LENAD) reports that in 2012 in Brazil, 62\% of men over 18 years, made the consumption of alcoholic beverages and $21 \%$ said that they smoked.

The world high smoking rate is the result of technological innovations, which made production easier cigarette, being possible to produce a cheap and affordable product, in addition to making the absorption of much more effective nicotine (Laranjeira, 2010). It also enhances the positive reinforcing properties and additionally contributes to the basic stimulating effects of nicotine in the central nervous system (Gherardi-Donato et al., 2011). Tobacco use has become the main global cause of preventable death worldwide, killing nearly 8 million people a year (WHO,2020). In 2005, the World Health Organization adopted the Framework Convention on Tobacco Control (FCTC) demonstrating global measures to strengthen tobacco control and save lifes (WHO, 2011). The prohibitions and warnings for tobacco promotion and its derivatives in the media, higher taxes and restrictions on access to these products by minors, were actions taken in order to prevent disease and reduce health costs (OMS, 2010). However, the consumption of tobacco in the population -is still very high, indicating that the use of this substance is being consumed mainly by its stimulating effect, similar to that described by amphetamine users, cocaine and crack (Marques et al., 2001). 
Although the number of participants in this study, which reported consumption of alcohol is lower than the average of the population, it is well known that the intake of these drugs promotes harmful effects to the individual (Martins, 2013) and also increases the chances of traffic accidents (Alessi \& Alves, 2015). The consumption of both drugs is the most likely in order to diminish the tensions arising from the work routine and even to be able to socialize with other peers (Nascimento et al., 2007).

Although the working conditions of truck drivers are significantly unfavourable characterized by irregular feeding, impaired personal hygiene, risk of violence in traffic, a few hours of rest, health problems (Alessi and Alves 2015) in general, the majority of respondents did not report the use of illicit drugs either with labor or recreational purpose at least in the last three months. However, $21 \%$ of subjects reported having used some psychoactive substance in the same period. The high use of illicit substances is also present in other occupations. Generally amphetamine is reported as one of the drugs most consumed among the population studied. Ferreira et al. (2008) found a prevalence of about $70 \%$ among respondents truck drivers who reported consumption of amphetamine throughout life. Teles et al. (2008) and Leyton et al. (2011) obtained prevalence of amphetamine $30 \%$ and 24\%, respectively. On the other hand, Souza et al. (2005) and Knauth et al. (2012) found lower prevalence rates between $11.1 \%$ and $12.4 \%$, data in accordance with those found in our study (12\%). For many years they use drugs because of its stimulating effects, in order to make the fastest brain work, leaving truck drivers in a state of alert and less sleep, allowing truck drivers to drive longer. Fortunately, it is being observed that over time, there was a reduction of this drug in this population.

The prevalence of other illicit drugs such as cocaine, cannabinoids, inhalants and hypnotics is less reported in the population of truck drivers. In the study of Knauth et al. (2012), in the Southern region of Brazil, $1 \%$ of truck drivers reported having used cocaine. In our study, we found that $5 \%$ of subjects reported consumption of such substances in the last three months. The value in this population is over that the global prevalence of use (UNODC, 2014). The estimation of global consumption of cocaine is $0,37 \%$, however our result showed a greater consume of this type of stimulant drug by truck drivers. Such variations are possible because the data collection instrument, its application and how to measure the consumption of amphetamines were not the same, the questionnaires utilized were constructed by the researchers, with simple questions about consume of drugs and they also were not validated. Some questions were made in the form of interviews, others by self-administered questionnaires, as well as containing questions that addressed the consumption of drugs ever in life, the previous year or the last 30 days.

There are many factors that lead participants to consume psychoactive substances for personal, professional and social reasons (Rezende, 2000). This consumption may put at risk to participants and in order to minimize these problems, measures are needed to prevent and treat pipes to these participants drug users. The UNODC in 2013, stressed that prevention is effective. The science of prevention shows that many of the interventions and drug prevention policies also prevent other risk behaviors. The ASSIST lists possible actions to be employed by participants who affirmed the use of drugs. Through it, $47 \%$ and $21 \%$ of patients need to receive brief intervention (BI) or be guided about the need to seek referral to specialized treatment (ST) for licit and illicit drugs. In order to prevent people who have considerable consumption of psychoactive substances, advance to a serious consumption, it is necessary implementing measures to promote the individual's awareness, combined with behavior change. In case of specialized treatments participants are very well attended, receiving the necessary therapeutic interventions in order to reverse the state of dependence of drugs and possible healing of participants.

In Brazil the article 165 of the Brazilian Traffic Code (1997), claims that driving under the influence of alcohol or any other psychoactive substance that determines addiction is considered a very serious offense resulting in a traffic ticket and suspension of the right to drive for twelve months. In 2016 it entered into force the Resolution 517, created by the Brazilian Conselho Nacional de Trânsito (CONTRAN), which requires the submission of drug testing of large window drug detection as a condition to obtain or renew a driver's license in the categories C, D and E, considered temporary unfit. Historically, results from previous studies suggest that drug use is fairly common among Brazilian truck drivers. Silva et al. (2003) conducted a study in 3 out of the 5 geographical regions of Brazil. A total of 728 urine samples were collected (517 in the southeast, 161 in the 
northeast, and 50 in the southern region) and of these, 5.6\% tested were positive for drugs. Amphetamine was present in $85.4 \%$ of positive samples, $4.9 \%$ for cocaine, cannabinoids were present in $4.9 \%$ of positive samples and $4,9 \%$ of multiple consumption of drugs. Leyton et al. (2011), conducted a drug test study in São Paulo state by 452 urine samples from truck drivers were analyzed. 9.3\% of the samples tested were positive for drugs. Amphetamines were present in 5.8\% of the total samples, cocaine in $2.2 \%$, and cannabis in $1.1 \%$ and $0,2 \%$ was positive for a combination of drugs. Oliveira et al. (2013), also developed another drug test study in São Paulo with 427 urine samples from truck drivers. 7\% tested positive for drugs. Amphetamine was present in $2,7 \%$ of positive samples, of those $25 \%$ associated with other drugs.

In the present study, the toxicological analysis was conducted by immunoassay analysis and showed that 10,5\% of samples were positive for drugs. In fact, the study indicates that the incidence of drug use in truck drivers at a gas station in Brazil is higher than the reported in other previously published studies. Cocaine was the most common drug with 5,2\%, cannabis with 2,6\%, amphetamine with 2,0\% and,with a combination of at least two drugs1,4\%. In Norwegian, Gjerde et al. (2012) conducted a drug test study of drivers whose oral fluids tested positive for alcohol or other drugs was very low. $0,1 \%$ were positive for alcohol, $0.2 \%$ for amphetamine, $0.7 \%$ for cannabinoids and $0.8 \%$ positive for cocaine. In Brazil, in Paraná state, $8.1 \%$ of the urine samples were positive for drugs with $4.8 \%$ positive for cocaine, $1.6 \%$ for amphetamine, and $1.6 \%$ for association among both (Peixe et al., 2014).

The analyses of urine samples in studies enabled the identification associated with drug use such as cocaine and cannabinoids and cocaine and amphetamine. Cocaine and amphetamines are drugs that have stimulants similar properties and when employed together can make the individual cases of intoxication with episodes of hypoglycemia and hyponatremia (low blood electrolytes causing what sodium in plasma is lower than normal) (CARLSON, 2009). It is known that cannabis is not a stimulant substance like amphetamine and cocaine, therefore the use of cannabis associated with use of cocaine is probably used as an anti-anxiety drug to reduce apprehension but it can affect psychomotor functions and can impair the user's ability to drive a truck safely (Julien, 1995).

The results allowed inferring that psychoactive substances continue to be sold and consumed in a gradual way in our country and actually, cocaine is the most commonly used drug among truckers. In 2011, the Agência Nacional de Vigilância Sanitária (ANVISA) implemented the Resolution - RDC No. 52, which prevents the production and legal marketing derived from amphetamine and the restriction might have led to a search for other stimulating substances among users of amphetamines (Peixe et al., 2014). Thus, it is possible that in order to obtain the same stimulating effects of amphetamine, the truckers look for another substance to produce equivalent results, such as cocaine, which although considered in Brazil an illicit drug, is easily acquired through illegal transactions. Another factor to consider is that amphetamines are part of the counterfeit drugs group in the country (Ames and Souza, 2012). Therefore, many truckers may have bought a product that did not have amphetamine compounds in its formulation, so they were less detected by immunoassay than the truck drivers reported in the questionnaire.

With the results of the multivariate analysis, it was possible to assess that $61 \%$ of the information provided, allowing to know how the information about truckers correlate, and the remaining 39\% are in the axes that were not represented. Through the hierarchical cluster analysis, it can be inferred that young truck drivers are more vulnerable to the use of drugs such as cocaine, as well as studies shown by Leyton et al. (2011) and Silva et al. (2003). Moreover, they also have health problems such as infection by STD throughout life. Because of the abuse in substances consumed, drivers should receive guidance during a brief intervention, so there is awareness and behavior change in relation to tobacco, amphetamine and cannabis. The consumption of amphetamine associated with younger age groups indicates that this group, possibly because of the short time profession, would have more difficulty dealing with the pressures at work and so resort to the use of this SPA, and they are more likely sexual practice with casual partners, contracting and spreading STIs, easily (Knauth et al., 2012). 
Parallel to this it was observed that individuals who are older, married or have a stable union of several years, demonstrated consumption of low-risk drugs without the need to apply measures to intervention or treatment in this profile of truckers. However preventive actions regarding the use of drugs are always necessary. In the study by Barros, 2011, performed with base on data from the National Sample Household in 2008 (PNAD/IBGE), observed that the prevalence of daily smoking in the north of the country is about $13 \%$, and the lower the education level of individuals, the higher the concentration of smokers in the population (Azevedo e Silva et al., 2009). Thus it can be argued that the absence of specific policies and programs that meet the needs of truck drivers in the health and education leads to the need of greater the strategies to be taken in order to address the group of individuals who live and has its acquired income mainly in the north, because a portion of this population need to be referred for specialist treatment for tobacco, since smoking is considered the leading cause of preventable death worldwide (WHO, 2014).

The examination of the urine is an important tool to verify the use of psychoactive drugs. However, a positive result does not necessarily mean that the driver was under the influence of drugs at the time of collection. Likewise, an individual to be classified as eligible to receive short intervention or be submitted to treatment, should not be stigmatized as a drug dependent because there are possibilities of the individual consuming, only occupational purposes and not for recreational use.

A challenge for the research was the questionnaire application model through an interview face-to-face can curb some answers because of the difficulty of reporting personal experiences with drugs in general. One possibility would be to use the instrument of self-administered form, but is often not well understood by the volunteer resulting in wrong and / or incomplete filling.

Despite the limitations, this study represents a great opportunity to monitor the prevalence of use of alcohol, tobacco, cocaine, marijuana, amphetamines among truck drivers in Brazil and to meet the behavioral walkers profiles that travel by BR 153 , crossing the central region - west of the country.

\section{Conclusion}

Given the results of this study, it appears that despite the truckers are largely responsible for boosting the Brazilian economy; they are highly vulnerable to tobacco use, alcohol, cocaine, cannabis and amphetamines. They require specific public health strategies to improve the quality of life, as well as measures to prevent and treat individuals who use illicit drugs in order to reduce engagement with traffic accidents.

Therefore, it is necessary the constant toxicological monitoring of this professional category on the highways, as well as more scientific studies that assess the social-emotional aspects that are related to the consumption of these drugs by truck drivers.

\section{Acknowledgments}

The authors would like to thank the research support from Departamento de DST, Aids e Hepatites Virais da Secretaria de Vigilância em Saúde (DDAHV/SVS/MS) and Escritório das Nações Unidas sobre Drogas e Crime (UNODC) and Coordenação de Aperfeiçoamento de Pessoal de Nível Superior (CAPES) and Fundação de Amparo à Pesquisa do Estado de Goiás (FAPEG) by supported Carla Danielle Dias Costa and Diogo Sousa Rodrigues, respectively.

\section{References}

Brasil. Agência Nacional de Trânsito Terrestre (ANTT). (2021). Registro nacional de transportadores rodoviários de cargas - RNTRC. http://www.antt.gov.br/index.php/content/view/4929/RNTRC__Registro_Nacional_de_Transportadores_Rodoviarios_de_Cargas.html 
Alessi A., \& Alves M. K. (2015). Habits of life and health of truck drivers in Brazil: a literature review. Ciência \& Saúde. 8 (3):129-136 http://dx.doi.org/10.15448/1983-652X.2015.3.18184

Azevedo e Silva G., Valente J. G., Almeida L. M., Moura E. C., \& Malta D. C. (2009). Tobacco smoking and level of education in Brazil, 2006. Revista de Saúde Pública. 43 (2): 48-56 http://dx.doi.org/10.1590/S0034-89102009000900007

Barros A. J. D., Cascaes A. M., Wehrmeister F. C., Martínez-Mesa J, \& Menezes A. M. B. (2011). Tobacco smoking in Brazil: regional inequalities and prevalence according to occupational characteristics. Ciência \& Saúde Coletiva. 16 (9): 3707-3716 http://dx.doi.org/10.1590/S1413-81232011001000008

Berti M. L., Oliveira S. R., Andrade L. M., Silva G. A., \& Garcia F. M. P. (2013). Knowledge on truckers amphetamines: an approach to light phenomenology. G\&S 4 (2): 68-76 http://dx.doi.org/10.18673/

Brasil. Agência Nacional de Vigilância Sanitária (ANVISA). Resolução - RDC nº 52, de 6 de outubro de 2011. (2011). Dispõe sobre a proibição do uso das substâncias anfepramona, femproporex e mazindol, seus sais e isômeros, bem como intermediários e medidas de controle da prescrição e dispensação de medicamentos que contenham a substância sibutramina, seus sais e isômeros, bem como intermediários e dá outras providências.

Brasil. Ministério da Saúde, Instituto Nacional de Câncer José Alencar Gomes da Silva (INCA). (2014). Política Nacional de Controle do Tabaco - Relatório de Gestão e Progresso 2011-2012, INCA

Brasil. Presidência da República, Subchefia para Assuntos Jurídicos. Lei no 9.503, de 23 de setembro de 1997. (1997). Institui o Código de Trânsito Brasileiro.

Brasil. Presidência da República, Subchefia para Assuntos Jurídicos. Resolução nº 517 de 29 de janeiro de 2015. (2015). Altera a Resolução CONTRAN nº 425, de 27 de novembro de 2012, que dispõe sobre o exame de aptidão física e mental, a avaliação psicológica e o credenciamento das entidades públicas e privadas de que tratam o art. $147, \mathrm{I}$ e $\$ \S 1^{\circ} \mathrm{a} 4^{\circ}$, e o art. 148 do Código de Trânsito Brasileiro.

Carmen del Río, M., Gómez, J., Sancho, M., \& Alvarez, F. J. (2002). Alcohol, illicit drugs and medicinal drugs in fatally injured drivers in Spain between 1991 and 2000. Forensic Science International. 127 (1-2): 63-70 http://dx.doi.org/10.1111/j.1556-4029.2006.00239

Carlson R. W., Atodaria S., Srivatsav N., \& Andhavarapu S. (2009). Intoxication with street drugs: Cocaine and amphetamines. Psychiatric Times. http://www.psychiatrictimes.com/articles/intoxication-street-drugs-cocaine-and-amphetamines

Confederação Nacional do Transporte (CNT). Boletim estatístico 2016. (2016). Available from: http://www.cnt.org.br/Boletim/boletim-estatistico-cnt (Acessed on 31.05.21).

Domingos J. B. C., Pillon S. C., Santos M. A., Santos R. Al., Jora N. P., \& Ferreira P. S. (2014). Alcohol use and health conditions among truck drivers. Revista de Enfermagem UERJ. 22 (6): 836-42 http://dx.doi.org/10.12957/reuerj.2014.4516

Ferreira L. O., Oliveira E. S., Raymond H. F., Chen S. Y., \& McFarland W. (2008). Use of time-location sampling for systematic behavioral surveillance of truck drivers in Brazil. AIDS and Behavior. 12: 32-38 http://dx.doi.org/10.1007/s10461-008-9386-0

Gherardi-Donato E. C. S., Lopes M., Santiago M. R., \& Corradi-Webster C. M. (2011). Characterization of tobacco consumption and dependence among workers at a higher education institution. SMAD, Revista Eletrônica de Saúde Mental Álcool e Drogas. 7 (3): 1-6.

Gjerde H., Normanna P. T., Christophersen A. S., Samuelsen S. O., \& Mørlanda J. (2011). Alcohol, psychoactive drugs and fatal road traffic accidents in Norway: A case-control study. Accident Analysis \& Prevention. 43 (2011): 1197-1203 http://dx.doi.org/10.1016/j.aap.2010.12.034

Greenacre M., \& Hastie T. (1987). The geometric interpretation of correspondence analysis. Journal of the American Statistical Association. 82 (398): $437-447$ http://dx.doi.org/10.1080/01621459.1987.10478446

Humeniuk R. E., Henry-Edwards S., Ali R. L., Poznyak V., \& Monteiro M. (2010). The Alcohol, Smoking and Substance Involvement Screening Test (ASSIST): manual for use in primary care.

Instituto Nacional de Ciência e Tecnologia para Políticas Públicas de Álcool e Outras Drogas (INDAP). (2014). II Levantamento Nacional de Álcool e Drogas (LENAD) - 2012. http://inpad.org.br/wp-content/uploads/2014/03/Lenad-II-Relat\%C3\%B3rio.pdf

Knauth D. R., LealI A. F., Pilecco F. B., Seffner F., Teixeira A. M. F. B. (2012). Staying awake: truck drivers' vulnerability in Rio Grande do Sul,Southern Brazil. Revista de Saúde Pública. 46 (5): 886-93 http://dx.doi.org/10.1590/S0034-89102012000500016

Laranjeira R. (2010). Drugs legalization and public health. Ciência \& Saúde Coletiva. 15 (3): 621-631 http://dx.doi.org/10.1590/S1413-81232010000300002

Lebart L., Morineau A., Lambert, T. (1994). SPAD. N: manual de referencia: versión 2.5: sistema compatible para el análisis de datos. CISIA.

Leyton V., Sinagawa D. M., Oliveira K. C. B. G., Schmitz W., Andreuccetti G., Martinis B. S., Yonamine M., \& Munoz D. R. (2011). Amphetamine, cocaine and cannabinoids use among truck drivers on the roads in the State of Sao Paulo, Brazil. Forensic Science International. 215 (2012): 25-27, http://dx.doi.org/10.1016/j.forsciint.2011.03.032

Marques A. C. P. R., Campana A., Gigliotti A. P., Lourenço M. T. C., Ferreira M. P., \& Laranjeira R. (2001). Consensus on the treatment of nicotine dependence. Revista Brasileira de Psiquiatria. 23 (4): 200-14 http://dx.doi.org/10.1590/S1516-44462001000400007

Martins O. A. (2013). Efeito do consumo de bebidas alcoólicas no organismo - uma revisão. Revista Eletrônica de Educação e Ciência (REEC) 3 (2): 07-10.

Nascimento E. C., Nascimento E., Silva J. P. (2007). Alcohol and amphetamines use among long-distance truck drivers. Rev. Saúde Púbica 41 (2): 290-3 http://dx.doi.org/10.1590/S0034-89102007000200017 
Oliveira L. G., Endo L. G., Sinagawa D. M., Yonamine M., Munoz D. R., \& Leyton V., 2013. Persistent amphetamine consumption by truck drivers in São Paulo State, Brazil, despite the ban on production, prescription, and use. Cadernos de Saúde Pública. 29 (9):1903-1909 http://dx.doi.org/10.1590/0102$311 \mathrm{X} 00029213$

Oliveira L. G., Leopoldo Kae., Gouvea M. J. C., Barroso L. P., Gouveia P. A. R., Muñoz D. R., \& Leyton V. (2016). Prevalence of at-risk drinking among Brazilian truck drivers and its interference on the performance of executive cognitive tasks. Drug and Alcohol Dependence. 166 (2016): 218-225 http://dx.doi.org/10.1016/j.drugalcdep.2016.07.019

Peixe T. S., Almeida R. M., Girotto E., Andrade S. M., \& Mesas A. E. (2014). Use of Illicit Drugs by Truck Drivers Arriving at Paranaguá Port Terminal, Brazil. Traffic Injury Prevention. 15 (7): 673-677 http://dx.doi.org/10.1080/15389588.2013.868893

Pereira, M. M, Mansur, A., Takada, J. Y, \& Leyton, V. (2021). Fatores demográficos e de risco cardiovascular associados ao uso de drogas por caminhoneiros no Estado de São Paulo, Brasil: um estudo transversal. Jornal Internacional de Pesquisa Ambiental e Saúde Pública. 18 (9), 4927. https://doi.org/10.3390/ijerph18094927

Rezende M. M. (2000). Analysis models of the use of drugs and the therapeutic intervention: some considerations. Revista Biociências. 6 (1): $49-55$.

Scherer, Juliana N. et al. (2020). Uso de drogas e comportamentos ao dirigir entre motoristas com e sem infrações relacionadas ao álcool. Tendências em psiquiatria e psicoterapia [online]. v. 42, n. 3 [Acesso em 31 de maio de 2021], pp. 230-238. Disponível em: <https://doi.org/10.1590/2237-6089-2019-0034>. Epub 19 de outubro de 2020. ISSN 2238-0019. https://doi.org/10.1590/2237-6089-2019-0034

Silva O., Greve J. M. D., Yonamine M., \& Leyton V. (2003). Drug Use by Truck Drivers in Brazil. Drugs: Education, Prevention \& Policy. 10 (2): 135-139 http://dx.doi.org/10.1080/0968763021000057727

Souza J. C., Paiva T., \& Reimão R. (2005). Sleep habits, sleepiness and accidents among truck drivers. Arquivos de Neuro-Psiquiatria. 63 (4):925-930 http://dx.doi.org/10.1590/S0004-282X2005000600004

Takitane J., Oliveira L. G., Endo L. G., Oliveira K. C. B. G., Muñoz D. R., Yonamine M., \& Leyton V. (2013). Amphetamine use by truck drivers on highways of Sao Paulo State: a risk for the occurrence of traffic accidents? Ciência \& Saúde Coletiva. 18 (5): 1247-1254 http://dx.doi.org/10.1590/S141381232013000500009

Teles A. S., Matos M. A., Caetano K. A. A., Costa L. A., França D. D. S., Pessoni G. C., Brunini S. M., \& Martins R. M. (2008). Comportamentos de risco para doenças sexualmente transmissíveis em caminhoneiros no Brasil. Revista Panamericana de Salud Publica. 24 (1):25-30 http://dx.doi.org/10.1590/S102049892008000700003

United Nations Office on Drugs and Crime (UNODC). (2013). International Standards About Drug Use Prevention. UNODC.

United Nations Office on Drugs and Crime (UNODC). (2014). World drug report 2014. UNODC, Vienna.

World Health Organization (WHO). (2002). The Alcohol, Smoking and Substance Involvement Screening Test (ASSIST): Development, Reliability and Feasibility. 97:1183-1194.

World Health Organization (WHO). (2011). Report on the global tobacco epidemic: warning about the dangers of tobacco, WHO.

World Health Organization (WHO). (2020). Tobacco. Available at: https://www.who.int/news-room/fact-sheets/detail/tobacco

Yonamine M., Sanches L. R., Paranhos B. A., Almeida R. M., Andreuccetti G., \& Leyton V. (2013). Detecting alcohol and illicit drugs in oral fluid samples collected from truck drivers in the state of São Paulo, Brazil. Traffic Injury Prevention. 14 (2):127-31 http://dx.doi.org/10.1080/15389588.2012.696222 